Marquette University

e-Publications@Marquette

History Faculty Research and Publications

History, Department of

$11-1-2014$

\title{
'The Military Mirror of Kail: Swordsmanship and a Medieval Text in Early Modern Japan
}

Michael Wert

Marquette University, michael.wert@marquette.edu

Published version. Das Mittelalter, Vol. 19, No. 2 (November 2014): 407-419. DOI. (C) 2014 Walter de Gruyter. Used with permission. 


\section{Michael Wert}

\section{'The Military Mirror of Kai’: Swordsmanship and a Medieval Text in Early Modern Japan}

Abstract: Swordsmanship emerged as a new field of knowledge in early modern lapan (1600-1868), a time of relative peace. During the most violent periods of Japanese history, the latter half of the medieval period (1185-1600), samurai conducted warfare mostly on horseback, using the bow and arrow, or by leading massive armies filled with soldiers who used pikes, halberds, and even firearms. In this paper, I will trace the origins of early modern swordsmanship to the late 16 th century during the transition between the medieval and early modem periods, when teachers of swordsmanship and their sword 'styles' first appeared in texts. Of these texts 1 will focus on 'The Military Mirror of Kai', purportedly written during the late 16th century, and a widely-read text among samurai of the early modern period. A mix of fact and fiction, the 'Mirror' became a source of fantasy and inspiration for samurai and non-samurai alike. It is also the earliest source of writing about swordsmanship, which was influenced by, and grew alongside, other medieval cultural arts such as Noh theater and tea ceremony.

Keywords: Japan, Samurai, 'The Military Mirror of Kai', Swordmanship, Warfare

\section{DOI 10.1515/mial-2014-0022}

The Military Mirror of Kai' (hereafter 'Military Mirror') is a fifty-nine volume collection of anecdotes, legends, and military teachings of the Takeda clan, one of Japan's most famous warrior families during the Warring States period (14671568), or what could be loosely called Japan's 'Middle Ages'. Published in the 1620 s, not long after the foundation of the Tokugawa shogunate (1600-1868), also known as early modern Japan, the 'Military Mirror' became a foundational text for early modern warriors who wanted to know how their predecessors, whom they idolized, lived and fought. This essay analyzes a few of the sections that address swordsmanship practice and two progenitors of early modern swordsmanship styles.

Throughout the twentieth century, popular culture created a romanticized image of samurai living and dying by the sword. As scholars have long pointed

Dr. Michael Wert: Marquette University, 1250 W. Wisconsin Avenue, Milwaukee, WI 53201-1881, U.S.A., E.Mail: michaelwert@yahoo.com 
out, however, throughout most of premodern Japanese history, the sword was not the primary weapon of the samurai. Mounted archers dominated many of the earliest battlefields. During a century of what one scholar has called the "violent fourteenth century", there was a rise in the frequency of sword wounds, according to injury reports from the time, but even then swords were only a secondary weapon. ${ }^{1}$ Swords became even more marginalized in the socalled Warring States period when warlords throughout Japan battled for control of territory. The scale of warfare expedited the development of mass combat, a development affected by the introduction of Western style firearms, and swords remained the equivalent of a sidearm in modern warfare.

Even though some of the earliest examples of Japanese literature are peppered with stories about duelists fighting with handheld weapons such as the sword and halberd, there were no writings on swordsmanship until the early modern period. In fact, the only texts on martial technique before the early modern period described the various procedures, customs, and ceremonies associated with mounted or standing archery. Even in those works, much of the instruction covers etiquette such as how to retrieve arrows shot during a competition or how to tie arrows together in a quiver.

During the early 17 th century, sword teachers began to organize and write about their swordsmanship, thus initiating a new field of knowledge. They professionalized their teachings, organizing them into 'styles' (ryüha) by developing unique sets of techniques, teaching methods, and systems of licensure that allowed experts to monopolize and police their art. The most notable feature of the training consisted of prearranged two-person sequences (kata) of attacks and defenses using wooden swords. The 17 th century experienced such a boom in martial art styles (swordsmanship, archery, grappling, etc.), that one practitioner published an encyclopedic history of martial arts in 1716 ('The Brief History of Martial Arts'), the first of its kind, to record martial art development. ${ }^{2}$

The irony is that the early modern period was a time of relative peace, far removed from the large-scale warfare that ravaged Japan a little over a century

1 Thomas Conlan, State of War. The Violent Order of Fourteenth-Century Japan (Michigan Monograph Series in Japanese Studies 46). Ann Arbor 2004. For more on the development of medieval warfare see Karl Friday, Samurai, Warfare and the State in Early Medieval Japan (Warfa. re and History). New York 2004; and Wayne Farris, Heavenly Warriors. The Evolution of Japan's Military, 500-1300 (Harvard East Asian Monographs 157). Cambridge MA 1992.

2 Three of the biggest chapters from this book have been published in English, see John Ro. gers, Arts of War in Times of Peace. Archery in 'Honcho Bugei Shoden'. In: Monumenta Nipponica 45/3 (1990), p. 253-284; Arts of War in Times of Peace. Swordsmanship in 'Honcho Bugei Shoden,' Chapter 5. In: Ibid. 45/4 (1990), p. 413-447; Arts of War in Times of Peace. Swordsmanship in 'Honcho Bugei Shoden', Chapter 6. In: Ibid. 46/2 (1991), p. 173-202. 
earlier. With some exceptions, the 250 or so warlords had settled on an uneasy peace following the Battle of Sekigahara (1600), allowing the Tokugawa clan and its relatives to install sucessive shogun in the capitol city of Edo (now Tokyo), while the remaining clans governed their own lands semi-autonomously. Peace helped expand the economy, and warriors were removed from the countryside, relocated to castle towns where they functioned as bureaucrats. This resulted in an identity crisis: how to be a warrior without war, a problem that evoked various responses, from the extreme view of accepting death before dishonor, to the more accepted emphasis on hereditary, civil-style service to the local domain, a process referred to as a "taming of the samurai". ${ }^{3}$

Warrior intellectuals throughout the early modern period criticized warriors of their day as being weak, lacking in discipline, and having lost their martial prowess. These criticisms also extended to commentary on swordsmanship. Some observers completely decried the rise of sword styles. The creation of attack and defense sequences, often practiced indoors on hardwood floor, and using wooden weapons, was thought to be ineffective on the battlefield. The Chinese studies scholar, Ogyû Sorai, famously referred to these styles as 'flower swordsmanship', a view that influenced interpretations of early modern swordsmanship to the present. ${ }^{4}$

\section{Swordsmanship in the 'Military Mirror of Kai'}

The influence of the 'Military Mirror' on early modern readers cannot be understated. A bestseller, it was read by warrior and commoners alike, and influenced popular culture, intellectual treatises, and history writing. It records the exploits of Takeda Shingen (1527-1573), one of the most famous warlords known to every school student in Japan. Even during the early modern period, however, the text was controversial. Some considered it a fabrication written during the 17 th century by Obata Kagenori (1572-1663), an ex-retainer of the Takeda clan who survived the clan's collapse. Kagenori claims that he simply received the collection from a relative, which he then published in 1621, and that the original writer was Kôsaka Masanobu, a retainer in Takeda's army. It might have also been a recording of oral accounts by Kōsaka and others, writ-

3 For more on this taming process see the work, Eiko Ikegami, The Taming of the Samurai. Honorific Individualism and the Making of Modern Japan. Cambridge 1995.

4 For more examples of such complaints, see Tominaga Kengo, Kendō gohyaku nenshi, Tokyo 1972 , p. 267 f. 
ten down by a Noh theater expert, Okura Hikojūrō, and Kōsaka's nephew Kasuga Sōjirō. Until recently, some historians tended to avoid the text, and for good reason; many details are historically inaccurate, some battles never occurred, and a few of the fifty-nine chapters are completely fictional. Since the 1990s, scholars have once again turned to the text, though cautiously, as a source for medieval warrior culture. ${ }^{5}$

Like the swordsmen of his day, Kagenori created a new field of knowledge - military science. His 'style' was dubbed Kôshû-ryû, or 'the style of the province of Kai', and was based on the content within the 'Military Mirror'. The 'Brief History of Martial Arts' lists Kōshū-ryū as the foundation for all subsequent military science styles. He is said to have taught as many as 2.000 students from around Japan, thus, doubts about the veracity of the text might also stem from Kagenori's celebrity that began after he published it. ${ }^{6}$

Throughout the 'Military Mirror', swordsmanship forms the foundation for all military knowledge, and is to be studied by the lowly foot soldier and land. holding warlord alike. ${ }^{7}$ The opening article in a preamble to five precepts on military science states:

Item. First, military strategy is based on swordsmanship. When not at war, warriors fight each other one-on-one in matches. Through these duels, one builds upon his training in order to win with certainty. Through sufficient mastery, a warrior will engage in numerous battles, emerge victorious, make a name for himself, and teach others. Then he will be known as a sword being. ${ }^{8}$

There is no description of what this swordsmanship looked like or whether med. ieval warriors were trained in attack and defense sequences that were popular during the early modern period, but it seems that much of the training consisted of dueling. Engaging in matches, the passage above suggests, would lead to more victories on the battlefield, and only after accruing practical experience could one become a sword teacher. Warrior officials during the early modern

5 For a more detailed introduction to the text in English, see Alexander Bennett, Neglected Treasure. The Koyo Gunkan. In: Diane Skoss (ed.), Sword and Spirit. Classical Warrior Traditions of Japan. Vol. 2. Berkeley Heights, New Jersey 1999, p. 35-57.

6 Cf. Arima Seiho, Kõyõ gunkan ron. In: Gunji shigaku 11 (1967), p. 59-75, here p. 63.

7 "Swordsmanship" is the commonly accepted term in the 'Military Mirror' for the Japanese word hyōhō, literally, 'soldiery' or 'soldier method'. It can also refer to military arts, martial arts, or military science more generally. This leaves open the possibility that a teacher of hyôho might actually teach other weapons as well. Other commonly used terms include the more straightforward 'swordsmanship' (kenjutsu), and other phrases that have 'sword' in the word.

8 Kōyō Gunkan chû. Ed. by Kōya Nakamura, Masayoshi Isogai and Harunori Hattori. Vol. 41. Tokyo 1965, p. 82. All translations are by the author. 
period often complained about the lack of martial training among warriors of their day. Peace and an expanding economy provided warriors with more opportunities to spend their time and money on wasteful pursuits such as gambling, visiting pleasure quarters, and buying fancy clothing. Thus many clan teachings contained similar calls for their retainers to continue training even off of the battlefield.

Just as swordsmanship was the basis for military strategy, so too was it important for creating proper leaders, even though they might never engage in personal combat themselves, leaving such dirty work to lower-ranking men. Nevertheless, warrior elites were not supposed to pursue swordsmanship as simply a performance art to display cultural capital by demonstrating knowledge of a particular style's movements. This is illustrated in the following passage, often quoted in writing about leadership in modern Japan,

There are four types of warlords who will destroy the house and province. They are: 1) stupid generals; 2) a warlord who is too clever: 3) a warlord who is too timid; and 4) a warlord who is too strong. First there is the foolish warlord. He is called a liar, a fool, and a twit. This is the kind of man who screws around, but is always stubborn. He is full of himself and because he is selfish, he forgets himself, spends too much time going on pleasure trips, engaged in moon or flower viewing, and sightseeing. At night he spends too much time playing with rare objects, or becomes caught up in some performance art. By happenstance he has some practice with the military arts of the bow and sword (hyoho), horseback riding, and rifle shooting, but since he has such a lax attitude, he carries himself like a performer. Anyway, he has no real understanding of the martial arts, yet thinks that he is always right because he is a land-holding warlord. ${ }^{9}$

Some of these traits can apply to leaders throughout world history but a few are culture specific. Moon and flower viewing, for example, were common amusements enjoyed by non-military noble families throughout Japan who followed cultural cues established by the highest ranking aristocrats living in Japan's ancient capitol city Kyoto. Powerful warriors, too, patronized artists and writers, bought artwork, and even became art participants, imitating their cultural superiors. One shogun, Ashikaga Yoshimasa (1436-1490), was repeatedly criticized throughout Japanese history for his interest in cultural pursuits over military and political matters. During the early modern period, warriors were expected to have some basic civil education; part of their 'taming' emphasized by military leaders. Skill in both the cultural and military arts, an idea that originated in China, influenced even the most battle-hardened warrior, but, as de-

9 Kő̀o Gunkan jo. Ed. by Koshihara Tetsurō. Vol. 11. Tokyo 1979, p. $183 \mathrm{f}$. 
scribed in the passage above, becoming too involved in artistic pursuits threatened to blur the lines that separated warriors from everyone else.

Criticizing a warrior for moving like a performer, most likely a reference to Noh actors, has several meanings. This is the same criticism issued by opponents of the swordsmanship phenomenon during the 17th century. It implied that someone moved in stylized motions with no meaning beyond simple display; the movements lack military applications.

There is a more direct connection between performance art and warrior culture that traces back to the medieval period. Noh became popular during the Warring States period and some warlords even brought scripts with them to the battlefield to memorize lines during breaks in the fighting. Noh thought also affected the development of swordsmanship. Yagyũ Munenori, the first to write extensively about swordsmanship, was influenced by Noh, Zen, and Chinese philosophy. Even the footwork in his style, Yagyũ Shinkage-ryũ, is taken from Noh. The style's texts only became well known long after the 17 th century, but, along with the teachings of a handful of other early 17th century styles, they inspired the hundreds of swordsmanship styles that existed by the end of the early modern period. ${ }^{10}$ Yagyū Shinkage-ryū was popular among warlords and other high ranking warriors during the peaceful early modern period. Other styles, and even separate martial arts, such as the use of the quarterstaff, became common among low-ranking warriors who were expected to use their techniques in official duties. During the first half of the 19th century, however, warlords eventually employed sword instructors who taught competitive fencing styles that had become popular among non-warriors too. One warlord even fired his domain's sword teacher, a master of Yagyū Shinkage-ryû, feeling that it was not as effective as newer rough and tumble styles."

\section{Progenitor Swordsmen and their Art}

The 'Military Mirror' was the oldest widely available text in the early modern period that described famous swordsmen and their styles. Anecdotes about swordsmen are brief, but they influenced the many apocryphal origin stories

10 For more on these influences on Yagyũ Shinkage-ryũ see Maki Morinaga, Secrecy in Japanese Arts. "Secret Transmission" as a Mode of Knowledge. New York 2005; and for Zen in Yagy Shinkage-ryū see Peter Haskel, Sword of Zen. Master Takuan and His Writings on Immovable Wisdom and the Sword Taie. Honolulu 2013.

11 Yamada Rie and Mayumi Tabata, Bakumatsuiki murahan ni okeru kenjutsu ryùha kaihen no ikisatsu. In: Taiikugaku kenkyũ 56/1 (2011), p. 143-155, here p. 149-151. 
retold by many swordsmen who trace their history into the mythic medieval past. Two creators of swordsmanship styles, Kamiizumi Nobutsuna and Tsukahara Bokuden, are arguably the most famous progenitors in the history of early modern swordsmanship, and both appear in the 'Military Mirror'. Many later swordsmanship histories cite the 'Military Mirror' when referring to these men. Unfortunately very little is known about either figure. Contemporary sources confirm their existence, but there are few details about the styles they created.

Of the two, Kamiizumi Nobutsuna (1508-1570s) appears first in a list of vanguard warriors who served the hero of the text, Takeda Shingen. Most of these warriors are not famous, but some are listed with details about their compensation or are have a one-line history. Kamiizumi's entry states that he asks to leave Shingen's army in order to train in swordsmanship. ${ }^{12}$ Several volumes later the text describes how he encountered Takeda's army. Kamiizumi initially served a minor warlord, Nagano Shinanokami, and tried to defend Minowa Casthe against Takeda's forces. Takeda won and,

Of about two hundred excellent warriors, there was one named Kamiizumi ise no kami. He was a samurat praised for his skill in martial arts, but he asked Shingen to be relieved of duty. His reason. 'He studied a sword style called Aisu Kage-ryũ, and from it created Shinkage-ryu. He wanted to train in swordsmanship, and asked to be relieved of duty. He was told that if he wanted to serve in the future, he should contact Shingen, but demurred, wanting just to focus on training. Thus Shingen allowed him to leave. ${ }^{13}$

It is commonly accepted that Aisu Kage-ryū, literally, the 'shadow style of Aisu', was created by a man named Aisu Ikō, although there is little known about him. Kamiizumi's 'new shadow' style became the basis for the Yagyū Shinkagemyû, thus solidifying his importance in the history of Japanese swordsmanship. ${ }^{14}$ We know that he existed as contemporary documents also noted that he taught swordsmanship in Kyoto, including among his students the then shogun, Ashikaga Yoshiteru. Given that the 'Military Mirror' is meant to praise Takeda Shingen, one might assume that Kamiizumi's refusal to remain in Shingen's service after the defeat of Kamiizumi's lord offended Shingen. Members of losing armies often switched to the victor's army without too much stigmatizing. If this particular anecdote was a later addition to the text, it could be a way of boosting Shingen's reputation by connecting him to a founding father of Japanese swordsmanship. Moreover, Shingen appears magnanimous, granting Kamiizumi

\footnotetext{
12 Kôo Gunkan taisei 1. Ed. by Sakai Kenji. Vol. 8. Tokyo 1994, p. 191.

13 Ibid., Vol. 11, p. 352.

14 Different sources claim that Kamiizumi studied other styles and with other teachers, but these are later, early modern sources.
} 
permission to retire from service, and also leaves open the possibility to return. In either case, the text suggests that Kamiizumi does not intend to enter the service of another lord, thus keeping his talent away from Shingen's rivals. Nothing more is said about Kamiizumi and there are no descriptions of his swordsmanship, unlike some tantalizing details about the style taught by Tsukahara Bokuden.

Bokuden has a larger presence in the 'Military Mirror' despite having no direct connection to Takeda Shingen. Bokuden, like Kamiizumi, was a 16th century swordsman who is said to have studied an older style, created his own style called Shintō-ryū ('new sword style') and tutored elites. Shintō-ryũ is widely acknowledged to be older than Kamiizumi's Shinkage-ryũ, and possibly even its predecessor, Aisu Kage-ryū. None of these details are recorded in the 'Military Mirror' but if the text is to be trusted, it suggests that Bokuden's Shintõ-ryũ had been widely regarded as a dominant style by the late 16th century, and if Obata Kagenori added to the text when he published it, at the very latest, by 1623 Shintō-ryũ was well known.

Unlike Kamiizumi's entries, which say nothing specific about his swordsmanship, the 'Military Mirror' gives some details about Bokuden's teachings:

Bokuden's "one sword" is split into three levels, called the "one sword" (hitotsu on ta. chi), "one position" (hitotsu no kurai), and "sword of one" (tachi hitotsu); this is the inner teaching. ${ }^{15}$

Here, "inner teaching" implies that the teaching is a secret, available only to students who have reached the highest level of training and are trusted by a style's master. Thus, even to this day, different translations of these terms are only best guesses based upon texts written much later in the early modern period, including those from Shintō-ryũ itself. For example, sometimes hitotsu tachi is translated as 'solitary sword' or 'single stroke'. It could also refer to a specific attack and defense sequence. The most common explanation is that each term above refers not to a specific technique, but an abstract concept. Terms such as 'the sword of heaven' and the 'sword of earth' could also refer to sword positions or abstract concepts or both. ${ }^{16}$ The 'Military Mirror' itself suggests that the 'one sword' is in fact a way of being, beyond any single teaching, an idea that can be grasped even by someone who has no training in any particular weapon style.

15 Kōyō Gunkan ge. Ed. by Koshihara Tetsurō. Vol. 40. Tokyo 1966, p. 69.

16 Ibid., p. 70. 
In either case, Shintō-ryū's reputation is also confirmed in the text where it is compared it to a putative opposite style called, Gyō-ryū (also Kyō-ryū), literally 'style of the capitol', i.e. Kyoto in the $16^{\text {th }}$ century. Gyō-ryū was the sword style practiced by Yamamoto Kansuke, one of Shingen's most famous generals featured in early modem Japanese popular culture, and a central character throughout the text. He is widely thought to be fictional and seems to be used as a thetorical device to demonstrate Shingen's wisdom. ${ }^{17}$ Another warlord, Imagawa Yoshimoto, for example, refused to employ Kansuke despite living in Imagawa's jurisdiction for some nine years. People said that Kansuke was a cripple, a nobody from the countryside, with no castle of his own, nor did he have any retainers. Shingen, however, overlooked these defaults because he recognized Kansuke's skill in swordsmanship and deep knowledge of military strategy. Regarding his swordsmanship style,

\footnotetext{
"Moreover, it was wrong for people to criticize Yamamoto Kansuke's swordsmanship for not being Shinto-ryù. Not everyone who does Shintó-ryũ is skilled, and not everyone who does Gyo-ryu is unskilled. He was so good that he had exploits with real swords and wooden swords. Whatever the path, one should praise skill." While Shingen employed Yamamoto to great benefit, the Imagawa clan's fortunes declined. ${ }^{18}$
}

On the surface, the moral of the story seems straightforward: the true value of a warrior does not lie in outward appearances, but in the depth of his knowledge and ability. But it also reveals the role that swordsmanship played in warrior society. Styles had reputations, which suggests that from their inception, they were meant as a form of social and cultural capital rather than, primarily, methods for conveying combat proficiency. The social and cultural capital value of swordsmanship accelerated in the 18th and 19th centuries when teachers added ceremonial gestures and abstract philosophy to attract students who valued such artistic flourishes.

Other members of Shingen's army cautioned against identifying too much with one style or becoming a sword specialist. According to Ogasawara Genyosai, a military advisor,

Samurai should learn the bow, rifle, the horse and swordsmanship, these four, more than anything else. They should train, think about what they're doing, make corrections, and discipline themselves. In so doing, one becomes adept and accepts students. Having disciples does not mean one is considered accomplished at martial arts. Being skilled

17 A few letters from Takeda Shingen addressed to a person named Yamamoto Kansuke, but spelled using different Chinese characters, have been found in recent years. Still, much of Yamamoto's feats are probably legendary.

18 Køyo Gunkan jo. Ed. by Koshihara Tetsuró. Vol. 7. Tokyo 1979, p. 195. 
and calling someone an archer, a shooter, a horseman, or a swordsman, will not eam the smiles of even one's own colleagues, they will consider you self-willed. Becoming sidetracked from one's job is not being a true warrior, so no matter how skilled you become, it's of no benefit to take students. ${ }^{19}$

Later early modern texts echoed this sentiment that only lower ranking warriors should become specialists in one particular martial art and work as teachers. The Yagyū clan was one notable exception, they were promoted to a warlord rank because they tutored the Tokugawa shogun, but even the Yagyũ began as middle ranking retainers. Moreover, early modern warriors were supposed to study not four, but as many as eighteen military arts, a concept based on Chinese military science, including swimming, spearmanship, and grappling. Certain arts, such as archery and equestrianism, remained the primary skills expected of a high ranking warrior, while grappling and use of the quarterstaff, techniques used in police-type work, were commonly studied by low ranking warriors. Perhaps the shift from four skills to eighteen reflects the decline in opportunities for real combat experience. Throughout the 'Military Mirror', various generals or military advisors commented about the need for experience over stylistic expertise.

The most thorough example of experience versus expertise in a particular style concerns a teaching about the three levels of martial prowess, in which Shintō-ryũ is evoked.

Obata Kazusa no kami used to say the following. It concerns three things, a sword expert (hyōhō tsukai), a sword master (hyōhổsha), and a sword being (hyōhōjin). First, the sword expert puts on a face mask, engages in some matches, and has the ability to teach peo. ple. Second, a sword master, knows the ins and outs of martial arts and has engaged in many matches. One example is the sword master Maebara Chikuzen. While standing in the corner of a tatami mat room holding a wooden sword or something, five or six men throw fans at him from a distance of about two or three ken (3.6 meters), and he can strike them down right before they touch his body. He can also cut several thin twisted strings with a split bamboo sword. With that same bamboo sword he can shatter a 62 plate helmet. His legs, hands, and body are excellent; he displays miraculous power. Obata talked about Tsukahara Bokuden, someone who trained hard. Bokuden trained around the country, taking with him three large hawks, three horses, and accompanied by about eighty men. He has trained hard and is respected by samurai of all types. Could we not call men like Bokuden sword masters? Lastly, there is the sword being. Of course this person is an expert in the martial arts. Even without amazing power he can still win matches and has several exploits. Men such as Yamamoto Kansuke who was killed during the Battle of Kawanakajima, or Namiai Bizen no Kami, who faced a group of 200 enemies by himself and killed seventy or eighty with a halberd (naginata) without injury. Regarding swordsmanship, it's difficult to say this and that (i.e. what is good

19 lbid., p. 159 f. 
and bad) when comparing masters like Bokuden or skilled men like Maebara Chikuzen, but thete is nothing to criticize in either. There are plenty of people who have seen them in battles and duels. Enemies and allies alike have seen these vigorous exploits and there is nothing to hide. This is especially true of Kansuke and Bizen who many people have seen in action. Warriors like these two are truly sword beings. ${ }^{20}$

Like the passage before it, this one suggests that having some skill, enough to teach swordsmanship is fine, but it is not the apex of martial achievement. One thinks of the modern day phrase 'those who can do, those who can't, teach'. Note as well that the sword expert described here is someone who uses equipment common in sword styles, such as protective armor. Sword masters are clearly respected over the sword expert, such as Maebara Chikuzen. And while he is regarded as a master with the sword, the description of his ability to strike down hand fans seems more a feat of trickery, an impressive display, rather than simple battlefield prowess.

Neither Kansuke nor Bizen's expertise is confined to style training like the sword expert or sword master, both men are beyond the institution of swordsmanship due to their actual battle experience. In fact, Obata, the author of this anecdote notes that the highest teaching of Shintō-ryū, the 'one sword', is this natural ability borne from resourcefulness and backed by combat experience. Continuing from the quotation above,

There are those who don't even know how to use a sword, but because they are on the warrior path (bushido), are martial beings [...]. During the Battle of Toishikuzure there was an enemy separated from his fellows and armed with a long spear. When Imai chased after him, the enemy, being, of course, a warrior of Uesugi Kenshin, changed the position of his spear, and was going to strike Imai from his horse. Because he was walking he had freedom of movement, but Imai was on a horse and couldn't move freely, the two positions were not equal. But Imai, the famed warrior that he was, tricked his opponent by calling out to him as if he were an ally. As the enemy lowered his spear to greet Imai, Imai's men moved in to attack. Imai is a martial being even though he could not use a sword and did not know much about martial arts. This is what Bokuden calls the one sword (hitotsu no tachi)."

The two passages do not deny the importance of perfecting a particular sword style. Bokuden and Chikuzen are considered masters by Obata, the author of this section and relative of Obata Kagenori, the compiler of the 'Military Mirror'. If the anecdote is an early modern addition to this putatively medieval text, then it might be an attempt to avoid offending early modern warriors who valued their status within a particular style of swordsmanship. Kagenori made his

20 Tetsuró (note 15), Vol. 40, p. 50 f.

21 Ibid., p.69. Uesugi Kenshin was Takeda Shingen's greatest rival. 
living by teaching samurai and publishing texts about the Takeda clan's military knowledge, at least as he defined it. But the anecdote about Imai empha. sizes the importance of experience and resourcefulness, claiming it as the highest teaching in swordsmanship - a lesson that cannot be taught but only experienced.

\section{Conclusion}

The sections about Bokuden and Kamiizumi might seem brief and insignificant, but they represent the earliest, widely available descriptions of these 'founding fathers' of Japanese swordsmanship as a new field of knowledge. Other Takeda. related treatises written by Obata Kagenori, private diaries that later became public, and later texts produced within styles descended from these two men, all give different versions of their lives. Some of these texts, however, cite the 'Brief History of Martial Arts', which, in turn relied on the 'Military Mirror', among other texts, or took information directly from the 'Military Mirror' itself. Anecdotes about these two swordsmen also help scholars understand the historical accuracy of the text. Works published after the 'Military Mirror' confirm the existence of both men and their role as important swordsmen in the late 16th century, suggesting that the text is partially reliable as a historical source.

It is difficult to determine the degree to which readers of the 'Military Mirror' accepted the message about the importance of sword training as vital to warrior identity. Indeed, readers might have enjoyed fantasizing about warriors of the past, men so unlike themselves, and lived the martial dream vicariously. Moreover, some intellectuals bemoaned general non-interest in swordsmanship among warriors as evidence of the warrior status group's decline. During the 19th century, leaders tried to reemphasize martial training to reinvigorate warriors with mixed success.

The 'Military Mirror' is a vast text that underwent several stages of writing, editing, compiling, and publishing, so commentary on swordsmanship varies. On the one hand, sword masters and their styles were deemed important, and training in any particular style was encouraged. On the other hand, experience on the battlefield trumped fidelity to sword styles. Did the lack of opportunities for battle, then, prohibit early modern warriors from ever fulfilling the martial prowess of their medieval ancestors? One response to this issue was the rise of competitive fencing beginning in the late 18th century; supporters of this trend believed it reintroduced reality into sword training. Critics pointed out that fencing with split bamboo swords and protective armor hardly mimicked real com. 
bat, but those complaints largely fell on deaf ears. By the 19th century, few warriors expected to battle their enemies with swords - the arrival of Western gunboats in Japanese waters led reformers to introduce Western rifles and infantry training. Fencing, which overshadowed the older form-based swordsmanship, was not expected to be useful in battle, but simply prepared bodies and minds for a new, modern Japanese warrior. But many continued to admire the stories in the 'Military Mirror of Kai', who, like them, lived during a transitionary moment in history. 